American Journal of Biochemistry and Biotechnology 6 (4): 275-278, 2010

ISSN 1553-3468

(C) 2010 Science Publications

\title{
Antimicrobial Properties of Newly Synthesized Derivatives of Coumarine
}

\author{
S. Govori, S. Spahiu, V. Kalaj, O.Leci, \\ A. Haziri and H. Ibrahimi \\ ${ }^{1}$ Department of Chemistry, Section of Organic and Biochemistry, \\ Faculty of Natural Science, University of Prishtina, \\ "Mother Teresa" Street 5, 10000 Prishtina, Republic of Kosova
}

\begin{abstract}
Problem statement: Coumarins are well known for their biological activity. On the basis of that we have synthesized some new derivatives of coumarine and investigated their antimicrobial properties. Approach: 4-Heteroaryl-coumarin-3-carbaldehydes 4(a-d) are synthesized by condensation of 4-chloro-coumarin-3-carbaldehydes 2 and corresponding heterorylamines 3(a-d) under reflux reaction conditions. Antimicrobial properties of new coumarins 4(a-d) are investigated and results are submitted for their activities against Staphylococcus aureus, Escherichia coli, Hafnia alvei, Pseudomonas aeruginosa and Enterobacter cloacae. Applying the Agar disc diffusion technique we measured diameters of the inhibition zone around discs which are previously wetted with N, N-DMF solution of compounds, 1,3 and $5 \mathrm{mg} \mathrm{L}^{-1}$. Results: The inhibition zone depends from concentrations and also from sort of bacteria. The inhibition zone differ from 0 to $30 \mathrm{~mm}$. Two sort of bacteria, Hafnia alvei and Pseudomonas aeruginosa, are resistant to these new synthesized compounds. Conclusion: From results we may conclude that these derivates showed moderate to high activity against Staphylococcus aureus, Escherichia coli and Enterobacter cloaco. Compounds 4(a-d) are more active against Staphylococcus aureus, E.coli and Enterobacter cloaco. Compounds 4(a-d) are not active against Hafnia alvei and Pseudomonas aeruginosa.
\end{abstract}

Key words: Coumarine Derivatives, Antimicrobial properties, Staphylococcus aureus, Pseudomonas aeruginosa, Escherichia coli, Enterobacter cloacae, Hafnia alvei

\section{INTRODUCTION}

Although coumarins have been known for many years, the researche about their properties such as anticoagulant (Garazd et al., 2005; Katritzky et al., 1996; Manolov and Danchev, 1995), antibacterial (Arora and Mathur, 1963), antiinflamatory (Al-Haiza et al., 2003), antioxidant, activities has become duty and responsibility for researchers to discover new methods of synthesizing new biological active coumarins.

In the course of our studies on the chemistry of coumarins and related structures (Haber et al., 1995; Govori et al., 2002), we have investigated reactions for the preparation of 4-heteroaryl-coumarin-3-carbaldehyde from 4-chlorocoumarin-3-carbaldehyde with different heteroarylamines. Antibacterial activities of new coumarine derivatives were tested in vitro against bacterial strains; Staphylococcus aureus, Escherichia coli, Hafnia alvei, Pseudomonas aeruginosa and Enterobacter cloacae (Philip et al., 2009; Azadeh and
Meon, 2009; Ghanbarpour et al., 2010; Rusli et al., 2009) by Agar disc diffusion technique.

\section{MATERIALS AND METHODS}

Melting points were determined with a Buechi apparatus. The IR spectra were recorded for $\mathrm{KBr}$ pellets with a Perkin Elmer $1725 \times$ FT IR spectrophotometer, ${ }^{1} \mathrm{H}-\mathrm{NMR}$ spectra were recorded on a Brucker AC $300(300 \mathrm{MHz})$ spectrometer with TMS as internal standard. Elemental analyses were performed in "Ruder Boskovic" Institute, Croatia.

General procedure for preparation of 4-heteroarylcoumarin-3-carbaldehydes 4(a-d): The solution of 4chlorocumarin-3-carbaldehyde $2(0.5 \mathrm{~g}, 24 \mathrm{mmol})$ and of appropriate heteroarylamine $3(\mathrm{a}-\mathrm{d})(24 \mathrm{mmol})$, in acetonitrile $(30 \mathrm{~mL})$ in presence of catalytical amount of triethylamine was refluxed for 2-4 h. After cooling the mixture was filtred off, washed with acetonitrile and recrystallised.

Corresponding Author: S. Govori, Section of Organic and Biochemistry, Department of Chemistry, Faculty of Natural Science, University of Prishtina, "Mother Teresa" Street 5, 10000 Prishtina, Republic of Kosova 
4-(4,6-dichloropyrimidin-2-ylamino)-coumarin-3carbaldehyde (4a): Yield: $45.85 \%$, m.p. $280{ }^{\circ} \mathrm{C}$ from mixture ethanol: DMF (3:1) IR $(\mathrm{KBr}) \mathrm{cm}^{-1}: 3350(\mathrm{~N}-$ $\mathrm{H}), 3120(\mathrm{C}-\mathrm{H}$ arom $), 1734-1664(\mathrm{C}=\mathrm{O}, \mathrm{CHO} ; \alpha-$ pir.);1610 ( $\mathrm{C}=\mathrm{N}) ; 1528-1420(\mathrm{C}=\mathrm{C}$ arom. $), 758(\mathrm{C}-\mathrm{C}$ arom). ${ }^{1} \mathrm{H}-\mathrm{RBM}\left(\mathrm{CDCl}_{3}\right) \quad$ (ppm):9-9.10 $\mathrm{s}$ $(1 \mathrm{H}, \mathrm{CHO}) ; 8.42-6.46 \mathrm{~m}(5 \mathrm{H} ;$ arom $), 3.92 \mathrm{~s}(1 \mathrm{H} ; \mathrm{N}-\mathrm{H})$, ${ }^{13} \mathrm{C}-\mathrm{RBM} \quad\left(\mathrm{DMSO}-\mathrm{d}_{6}\right) \quad$ (ppm): $\mathrm{CHO}(179.30)$;C$\mathrm{NH}(163.14) ; \mathrm{C}-\mathrm{Cl}(161.57) ; \mathrm{C}=\mathrm{O} \quad$ (159.65); $\mathrm{C}$ arom.(154.19- 104.01);DMSO (40.34-34.43). Anal: Calculated for $\mathrm{C}_{13} \mathrm{H}_{6} \mathrm{~N}_{4}$ : (C,59.99\%), (H, 2.75\%), $(\mathrm{N}, 12.44 \%) \quad$ Found: $\quad(\mathrm{C}, 60.00 \%), \quad(\mathrm{H}, 2.90 \%), \quad(\mathrm{N}$, $12.38 \%)$.

\section{4-(2-chloro-6,7-dymethoxyquinazolin-4-ylamino)-} coumarin-3-carbaldehyde (4b): Yield: 43,87\%,m.p. $300^{\circ} \mathrm{C}$ from ethanol: DMF (3:1). IR $(\mathrm{KBr}) \mathrm{cm}^{-1}: 3305-$ $3122(\mathrm{~N}-\mathrm{H}), 3001(\mathrm{C}-\mathrm{H}$ arom),3483-3122 (N-H), 3001 $(\mathrm{C}-\mathrm{H}$ arom $), 2920(\mathrm{C}-\mathrm{H}$ al), $1648(\mathrm{C}=\mathrm{O}), 1624(\mathrm{C}=$ $\mathrm{N}), \quad 1516-1417(\mathrm{C}=\mathrm{C}$ arom $) .{ }^{1} \mathrm{H}-\mathrm{RBM}\left(\mathrm{CDCl}_{3}\right)$ (ppm):9.60 s (1H;CHO);8.03-6.74 m (7H;ar.); $4.24 \mathrm{~s}$ $(1 \mathrm{H} ; \mathrm{N}-\mathrm{H}) ; 5.63-5.27$ ss $(6 \mathrm{H} ; 2 \mathrm{OCH} 3)$. Anal: Calculated for $\mathrm{C}_{22} \mathrm{H}_{20} \mathrm{~N}_{3}$ : $(\mathrm{C}, 59.80 \%),(\mathrm{H}, 4.56 \%),(\mathrm{N}, 9.51 \%)$. Found: (C, 60.00\%), (H, 4.29\%), (N, 9.44\%).

\section{4-(5-bromotiazol-2-ylamino)-coumarin-3-}

carbaldehyde (4c): Yield: $51.19 \%$. m.p. $298^{\circ} \mathrm{C}$ from acetic acid. IR $(\mathrm{KBr}) \mathrm{cm}^{-1}: 3350(\mathrm{~N}-\mathrm{H}), 1735-1702(\mathrm{C}$ $=\mathrm{O}, \mathrm{CHO}) 1654(\mathrm{C}=\mathrm{N}), 1560-1458(\mathrm{C}=\mathrm{C}$ arom $) .{ }^{1} \mathrm{H}-$ $\mathrm{RBM}\left(\mathrm{CDCl}_{3}\right)(\mathrm{ppm}): 9.32 \mathrm{sd}(1 \mathrm{H} ; \mathrm{CHO}) ; 8.49-6.08 \mathrm{~m}$ (5H;arom); 3.69-3.33 d (1H;NH). Anal: Calculated for $\mathrm{C}_{14} \mathrm{H}_{10} \mathrm{~N}_{2}$ : (C, 45.92\%), (H, 2.75\%), (N, 7.65\%). Found: (C, 45.27\%), (H, 2.97\%), (N, 7.80\%).

\section{4-(2-chloropyridin-3-ylamino)-coumarin-3-}

carbaldehyde (4d): Yield: $54 \%$, m.p. $215^{\circ} \mathrm{C}$ from ethanol. IR $(\mathrm{KBr}) \mathrm{cm}^{-1}: 3330(\mathrm{~N}-\mathrm{H}), 3055(\mathrm{C}-\mathrm{H}$ arom), $1735(\mathrm{C}=\mathrm{O}, \mathrm{CHO} ; \alpha$-piron $), 1610(\mathrm{C}=\mathrm{N})$ 1508-1458 $\left(\mathrm{C}=\mathrm{C}\right.$ aromatic). ${ }^{1} \mathrm{H}-\mathrm{RBM}\left(\mathrm{CDCl}_{3}\right) \quad$ (ppm):9.32 $\mathrm{sd}$ $\left({ }^{1} \mathrm{H}\right.$;CHO);8.49-6.08 m $(5 \mathrm{H} ;$ arom $) ; 3.69-3.33$ d $(1 \mathrm{H} ; \mathrm{NH})$. Anal: Calculated for $\mathrm{C}_{16} \mathrm{H}_{12} \mathrm{~N}_{2}:(\mathrm{C}, 60.87 \%)$, $(\mathrm{H}, 3.83 \%),(\mathrm{N}, 8.87 \%)$. Found: $(\mathrm{C}, 60.04 \%),(\mathrm{H}$, $3.75 \%),(\mathrm{N}, 8.80 \%)$.

The antimicrobial activity of compounds 4(a-d) was determined by Agar disc diffusion technique. Coumarin samples were tested in vitro against bacterial strains; Staphylococcus aureus, Escherichia coli, Hafnia alvei, Pseudomonas aeruginosa and Enterobacter cloaco, were incubated at $37^{\circ} \mathrm{C}$ during a period $24 \mathrm{hrs}$ and the inhibition zones were measured. The compounds were tested at three different concentrations, 1,3 and $5 \mathrm{mg} \mathrm{mL}^{-1}$ in DMF.

\section{RESULTS}

Nucleophylic substitution of 4-chloro-coumarin-3carbaldehyde (2) by corresponding aromatic amines $3(\mathrm{a}-\mathrm{d})$, has given the corresponding 4- heteroarylaminocoumarin-3-carbaldehydes 4(a-d) in good yields.

The structure of synthesized coumarins 4(a-d) were determined from IR, ${ }^{1} \mathrm{H}-\mathrm{NMR},{ }^{13} \mathrm{C}$-NMR spectra and elementary analysis (Fig. 1).<smiles>O=Cc1c(Nc2nc(Cl)cc(Cl)n2)c2ccccc2oc1=O</smiles>

(4a)<smiles>COc1cc2nc(Cl)nc(Nc3c(C=O)c(=O)oc4ccccc34)c2cc1OC</smiles>

(4b)<smiles>O=Cc1c(Nc2cccnc2Cl)c2ccccc2oc1=O</smiles>

(4c)<smiles>O=Cc1c(Nc2nc(Br)cs2)c2ccccc2oc1=O</smiles>

(4d)

Fig. 1: Structure of Coumarine derivatives 4 (a-d) 
Am. J. Biochem. \& Biotech., 6 (4): 275-278, 2010

Table 1: Microbiological activity of newly synthesized coumarin derivatives

\begin{tabular}{|c|c|c|c|c|c|c|}
\hline Test compound & Concentration & $\begin{array}{l}\text { E.Coli } \\
\text { ATCC }{ }^{\circledR} 25922\end{array}$ & $\begin{array}{l}\text { S.Aureus } \\
\text { ATCC }{ }^{\circledR} 25923\end{array}$ & $\begin{array}{l}\text { Pseudomonas } \\
\text { aeruginosa } \\
\text { ATCC } ® 27853\end{array}$ & $\begin{array}{l}\text { Hafnia alvei } \\
\text { PTCC } ₫ 2005\end{array}$ & $\begin{array}{l}\text { Enterococcus } \\
\text { cloacae } \\
\text { PTCC } ® 2005\end{array}$ \\
\hline \multirow[t]{3}{*}{$4 a$} & 1 & 17 & 23 & 0 & 0 & 17 \\
\hline & 3 & 17 & 23 & 0 & 0 & 18 \\
\hline & 5 & 27 & 27 & 0 & 0 & 18 \\
\hline \multirow[t]{3}{*}{$4 b$} & 1 & 20 & 22 & 0 & 0 & 22 \\
\hline & 3 & 20 & 25 & 0 & 0 & 20 \\
\hline & 5 & 20 & 30 & 0 & 0 & 15 \\
\hline \multirow[t]{3}{*}{$4 c$} & 1 & 0 & 29 & 0 & 0 & 10 \\
\hline & 3 & 15 & 27 & 0 & 0 & 15 \\
\hline & 5 & 18 & 20 & 0 & 0 & 17 \\
\hline \multirow[t]{3}{*}{$4 d$} & 1 & 20 & 0 & 0 & 0 & 18 \\
\hline & 3 & 20 & 0 & 0 & 0 & 0 \\
\hline & 5 & 23 & 0 & 0 & 0 & 0 \\
\hline
\end{tabular}

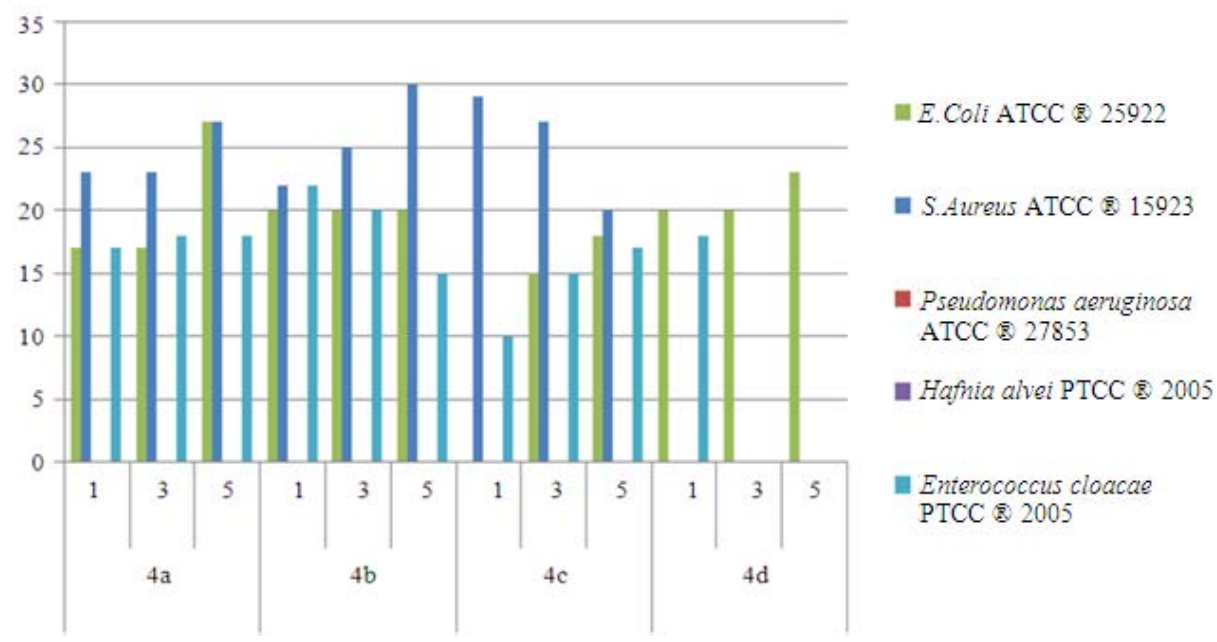

Fig. 2: Graphs of microbiological activity results for compounds 4(a-d)

Continuation to our study we examined the antimicrobial activity of synthesized compounds 4(a-d). Our investigation is directed toward their activity against Staphylococcus aureus, Escherichia coli, Hafnia alvei, Pseudomonas aeruginosa and Enterobacter cloaco. Applying the disc method we have measured diameters of the inhibition zones around disc which are previously wetted with DMF solution of the samples examined $\left(1,3\right.$ and $\left.5 \mathrm{mg} \mathrm{mL}^{-1}\right)$ were applied (Table 1).

\section{DISCUSSION}

The antimicrobial activity of synthesized coumarins is shown in Table 1 presented with graph (Fig. 2). From the results, we saw that new synthesized coumarins 4(a-d) show antibacterial activity against some bacteria. Compound 4a show activity against three bacteria, E. coli, S.Aureus and E. Cloaco. We found that if we increase the concentration of compound $4 \mathrm{a}$ the diameter of inhibition zone will not increase as we have expected. The Compound 4a don't show any activity against the $\mathrm{P}$. Aeuriginosa and $\mathrm{H}$. alvei. Compound $4 \mathrm{~b}$ show activity against E. coli, S.Aureus and E. Cloaco, but in the case of E. coli and E. Cloaco, if we increase the concentration of compound $4 \mathrm{~b}$, the activity will not change. But to the S. Aureus, if we increase concentration the inhibition zone will increase. Coumarine derivative $4 \mathrm{c}$ show antibacterial activity but in case of S. Aureus if we increase concentration of compound $4 \mathrm{c}$, the activity of this compound will decrease. Compound $4 \mathrm{~d}$ show activity against $\mathrm{E}$. coli and also in the concentration of $1 \mathrm{mg} \mathrm{L}^{-1}$ show activity against E. Cloaco. If we increase concentration the activity is zero against $E$. Cloaco.

Two bacteria, P. Aureiginosa and H. Alevei are resistant to all this compounds and also they are resistant to all this three different concentrations. 
Am. J. Biochem. \& Biotech., 6 (4): 275-278, 2010

\section{CONCLUSION}

From results we may conclude that these coumarin derivatives were shown moderate to high activity against Staphylococcus aureus, Escherichia coli and Enterobacter cloaco. Compounds 4(a-d) are more active against Staphylococcus aureus, E. coli and Enterobacter cloaco.

Compounds 4(a-d) are not active against Hafnia alvei and Pseudomonas aeruginosa.

\section{ACNOWLEDGMENT}

The researchers acknowledge the financial support received from the University of Prishtina, Kosova.

\section{REFERENCES}

Al-Haiza, M.A., M.S. Mostafa and M.Y. El-Kady, 2003. Synthesis and biological evaluation of some new coumarin derivatives. Molecules, 8: 275-286. DOI: $10.3390 / 80200275$

Arora, R.B. and C.N. Mathur, 1963. Relationship between structure and anticoagulant activity of coumarin derivatives. Brit. J. Pharmacol., 20 : 2935 .

http: http://www.ncbi.nlm.nih.gov/pmc/articles/PMC170 3756/

Garazd, Y.L., E.M. Kornienko, L.N. Maloshtan, M.M. Garazd and V.P. Khilya, 2005. Modified coumarins. 17. synthesis and anticoagulant activity of 3,4-cycloannelated coumarin dglycopyranosides. Chem. Natural Compounds, 41: 508-512. DOI: 10.1007/s10600-005-0194-8

Govori, S., V. Kaljaj, V. Rapic, L. Kaljaj and S. Djakovic, 2002. synthesis and structure of some 3, 4-annelated coumarin systems. Heterocycl. Commun., 8: 129-134.
Heber, D., I.C. Ivanov and S.K. Karagiosov, 1995. The vilsmeier reaction in the synthesis of 3-substituted [1] benzopyrano [4,3-b]pyridine-5-ones. an unusual pyridine ring closure. J. Heterocycl. Chem., $\quad 32$ : 505-509. DOI: $10.1002 /$ jhet.5570320221

Manolov, I. and N.D. Danchev, 1995. Synthesis, toxicological and pharmacological assessment of some 4-hydroxycoumarin derivatives. Eur. J. Med. Chem. Chim., 30: 531-536. DOI: 10.1016/02235234(96)88266-3

Katritzky, A.R., 1996. In Comprehensive Heterocyclic Chemistry. 1st Edn., Elsevier Science and Technology, ISBN: 0080420729, pp: 11628.

Philip, K., N.A. Malek, W. Sani, S.K. Shin and S. Kumar et al., 2009. Antimicrobial activity of some medicinal plants from Malaysia. Am. J. Applied Sci., 6: 1613-1617. DOI: 10.3844/ajassp.2009.1613.1617.

Azadeh, B.F. and S. Meon, 2009. Molecular characterization of Pseudomonas aeruginosa UPM P3 from oil palm rhizosphere. Am. J. Applied Sci., 6: 1915-1919. DOI: 10.3844/ajassp.2009.1915.1919

Ghanbarpour, R., M. Salehi, R. Ghanbarpour and M. Salehi, 2010. Determination of adhesin encoding genes in Escherichia coli isolates from omphalitis of chicks. Am. J. Anim. Veter. Sci., 5: 91-96. DOI: 10.3844/ajavsp.2010.91.96

Rusli, F.M., M.S. Mohamed, R. Mohamad, N.N. Tri Puspaningsih and A. A. Ariff, 2009. Kinetics of xylanase fermentation by recombinant Escherichia coli DH5 $\alpha$ in shake flask culture. Am. J. Biochem. Biotechnol., 5: 109-117. DOI: 10.3844/ajbbsp.2009.109.117 